\title{
Induction of resistance in pepper against Xanthomonas euvesicatoria by $\beta$-aminobutyric acid
}

\author{
Ali Safaie Farahani $^{1} \cdot$ S. Mohsen Taghavi ${ }^{1}$
}

Received: 7 July 2016 / Accepted: 7 December 2016 / Published online: 16 December 2016

(C) Australasian Plant Pathology Society Inc. 2016

\begin{abstract}
Xanthomonas euvesicatoria is one of the most destructive pathogens of pepper that results in serious yield loss worldwide. Previous studies confirmed that $\beta$-aminobutyric acid (BABA) induces resistance in plants against a variety of pathogens. A promoted resistance of pepper induced by BABA to $X$. euvesicatoria was demonstrated in this study. Additionally, induction of catalase and pathogenesis-related gene 1 during the BABA-induced resistance was confirmed. Our data provides useful information for the development of disease management programs.
\end{abstract}

Keywords $\beta$-aminobutyric acid · Catalase · Pepper · Pathogenesis-related gene $1 \cdot$ Xanthomonas euvesicatoria

In recent years, the possibility of induced resistance in plants against different pathogens using chemical inducers has opened up new alternatives for management of plant diseases. $\beta$-aminobutyric acid (BABA) is a non-protein amino acid compound that has been shown to mediate induction of resistance in some plant species versus a broad range of plant pathogens including fungi, nematodes, viruses and bacteria (Justyna and Ewa 2013; Baccelli and Mauch-Mani 2016). Plants employ various strategies to defend against pathogens. Production and accumulation of pathogenesis-related (PR) proteins in plants are important defense mechanisms in response to pathogen invasion. PR proteins are divided into 17 groups according to their properties and functions (Ebrahim

S. Mohsen Taghavi

mtaghavi@shirazu.ac.ir

1 Department of Plant Protection, College of Agriculture, Shiraz University, Shiraz, Iran et al. 2011). The role of $P R$ genes in induced resistance by BABA was investigated earlier (Zimmerli et al. 2001; Cohen 2002). Reactive oxygen species (ROS) are produced in plants upon pathogen attack. On the other hand, plants produce antioxidant enzymes such as catalase (CAT) to protect themselves versus direct toxic effects of ROS (Mittler et al. 2004). Accumulation of antioxidant enzymes during enhanced resistance of plants against different stresses induced by BABA has been previously demonstrated (Sahebani and Hadavi 2009; Hossain et al. 2012).

Bacterial spot caused by Xanthomonas euvesicatoria is an economically important disease of pepper worldwide (Kousik and Ritchie 1996a). Although BABA has been widely used to enhance resistance against a variety of plant pathogens, to date, there are no studies about application of BABAmediated induced resistance to $X$. euvesicatoria in pepper. Therefore, the objective of this study was to investigate the efficacy of BABA on disease severity of bacterial spot in pepper plants. Moreover, to extend our understanding about the probable mechanisms involving in induced resistance, the expression of $P R-1$ and $C A T$ was investigated during enhanced resistance of pepper against $X$. euvesicatoria.

The pathogen used for this experiment (X. euvesicatoria Xeu3)- deposited in International Collection of Microorganisms from Plants (ICMP), accession number: ICMP 22075 - was originally isolated from pepper in East Azerbaijan (north-western Iran) in 2013 (Osdaghi et al. 2016). To survey the effect of BABA on the bacterial growth in vitro, an overnight of culture with a density of $10^{9} \mathrm{CFU} / \mathrm{ml}$ was diluted 1000 times in the same medium (nutrient broth) complemented with BABA to the final concentration of $200 \mu \mathrm{l}$. The media were placed on a shaker $(200 \mathrm{rpm})$ at $28^{\circ} \mathrm{C}$. A control treatment not containing BABA was prepared under the same conditions. The bacterial concentration was measured by optical density $\left(\mathrm{OD}_{600}\right)$ after 5 and 10 h. Five 
replicates were used for each treatment. Pepper seeds (Capsicum annum) were sown in quartz sand in 10-cm plastic pots in a growth chamber. BABA at concentration of $200 \mu \mathrm{M}$ was sprayed onto the leaves of five-week-old plants. Distilled water was sprayed onto the seedlings as a control. For inoculum production, the bacterium was grown overnight on nutrient agar at $28^{\circ} \mathrm{C}$. Bacterial suspensions were adjusted to a concentration of about $10^{8} \mathrm{CFU} / \mathrm{ml}$ in sterile distilled water. Plants were treated with BABA or water $24 \mathrm{~h}$ prior to spraying the bacterial inoculum $(150 \mu \mathrm{l})$ onto each leaf. Plants were incubated at $28^{\circ} \mathrm{C}$ with 16 -h light daily and $70 \%$ relative humidity. Symptoms of the disease were scored at 7 and 14 day intervals post pathogen inoculation (dpi) using the following scale: $0=$ no lesions observed, $1=$ less than $1 \%$ leaf area diseased, $2=1$ to $10 \%$ leaf area diseased, $3=11$ to $20 \%$ leaf area diseased, $4=21$ to $35 \%$ leaf area diseased, $5=36$ to $50 \%$ leaf area diseased, $6=51$ to $65 \%$ leaf area diseased, $7=66$ to $80 \%$ leaf area diseased, $8=81$ to $99 \%$ leaf area diseased, and $9=$ complete defoliation (Kousik and Ritchie 1996b). After assessment, the leaves were harvested at 12, 24, 48 and $72 \mathrm{~h}$ post pathogen inoculation (hpi) and RNA isolation was performed using a RNA extraction kit (DENAzist, Iran), according to manufacturer's protocol. RNA quality and quantity was determined by agarose gel electrophoresis and spectrophotometry. Synthesis of cDNA was carried out on total RNA using a commercial kit (Fermentas, Lithuania) following the manufacturer's instructions. Real-Time PCR experiments were performed using RealQ PCR $2 \times$ Master Mix (Ampliqon, Denmark). Primers used in this study are listed in Table 1. The PCR mixture contained $10 \mu \mathrm{l}(2 \times)$ SYBR green Master Mix, $100 \mathrm{ng}$ of cDNA, $0.5 \mu \mathrm{l}$ of $10 \mu \mathrm{M}$ of each forward and reverse primers with a total volume of $20 \mu \mathrm{l}$ which was adjusted with water. Thermal cycling conditions included $95 \mathrm{C}$ for $5 \mathrm{~min}, 35$ cycles of $95 \mathrm{C}$ for $1 \mathrm{~min}, 65 \mathrm{C}$ for $2 \mathrm{~min}$, and $72^{\circ} \mathrm{C}$ for $1 \mathrm{~min}$, with a final extension at $72^{\circ} \mathrm{C}$ for $10 \mathrm{~min}$. Relative gene expression was measured using the comparative $2^{-\Delta \Delta \mathrm{Ct}}$ according to the method described by Livak and Schmittgen (2001). Seven plants were used for greenhouse experiments per treatment and the experiments were repeated twice. Four replicates were used for real-time assay per each sample. Statistical analysis was performed using SAS 9.1 (SAS Institute, Cary, NC, USA) and a probability of $p<0.05$ was considered significant. The means were separated by Duncan's multiple range tests.

No significant difference was found in bacterial growth in vitro between BABA and control treatments (Fig. 1). Our results showed that pre-treatment with BABA lead to significant decrease in bacterial spot disease severity at 7 and 14 dpi (Fig. 2). Pre-treatment with BABA increased expression of PR-1 at all time points compared to the control. The highest expression was found at 12 hpi (Fig. 3). Moreover, a significant increase was observed in expression of CAT in BABA treatment compared to the control at 12, 24 and 48 hpi (Fig. 4). 


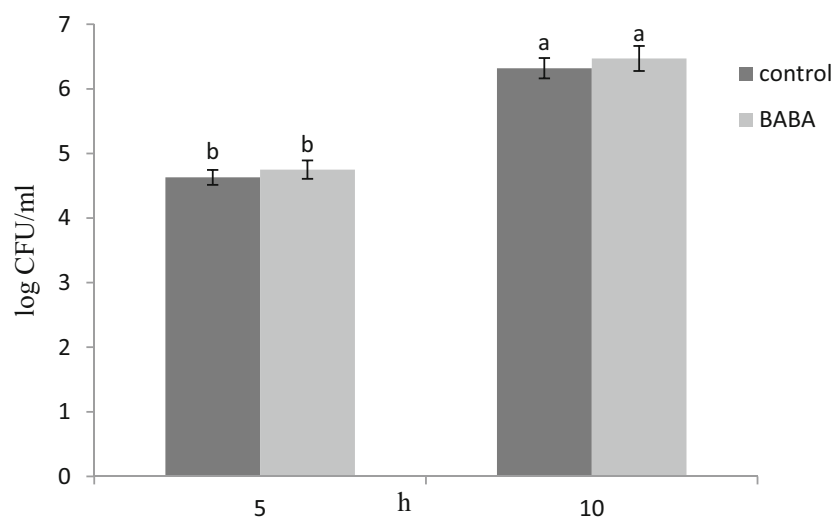

Fig. 1 Effect of BABA on growth of X. euvesicatoria in vitro. There was no significant difference in population of the bacterium in nutrient broth between BABA and control treatments at the both time points

Our results revealed that BABA does not have a direct toxic effect on $X$. euvesicatoria. The lack of antimicrobial activity of BABA against several bacterial pathogens like Erwinia amylovora (Hassan and Buchenauer 2007) and Pectobacterium carotovorum subsp. carotovorum (Safaie Farahani et al. 2016) has been reported. By contrast, toxic effects of BABA at high concentrations on some fungal pathogens such as Penicillium italicum (Tavallali et al. 2008), Botrytis cinerea (Fischer et al. 2009) and Sclerotinia sclerotiorum (Marcucci et al. 2010) have been observed. Our data confirmed that BABA increases resistance of pepper to $X$. euvesicatoria. Induction of some defense genes in primed plants by BABA upon pathogen invasion have been documented (Justyna and Ewa 2013; Baccelli and MauchMani 2016). Expression of $C A T$ and $P R-1$ during BABAinduced resistance of pepper to $X$. euvesicatoria was demonstrated in this study. In Arabidopsis, BABA-induced resistance to Pseudomonas syringae pv. tomato by activating of PR-1 (Zimmerli et al. 2000) which is consistent with this present study. Kamble and Bhargava (2007) showed the ability of BABA to protect brown mustard against Alternaria brassicae, which was also associated with increased expression of $P R-1$.

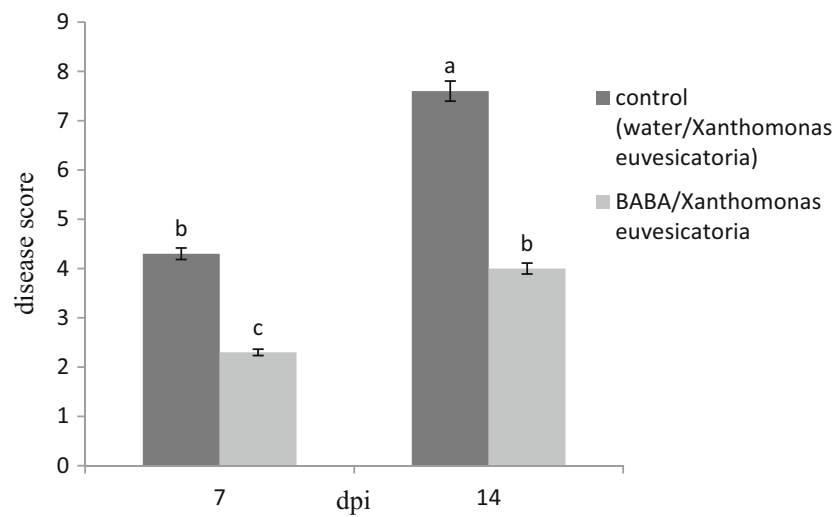

Fig. 2 Effects of BABA on disease score of bacterial spot of pepper at 7 and $14 \mathrm{dpi}$. Significant difference was found between plats treated with $\mathrm{BABA}$ and the control at the both time points

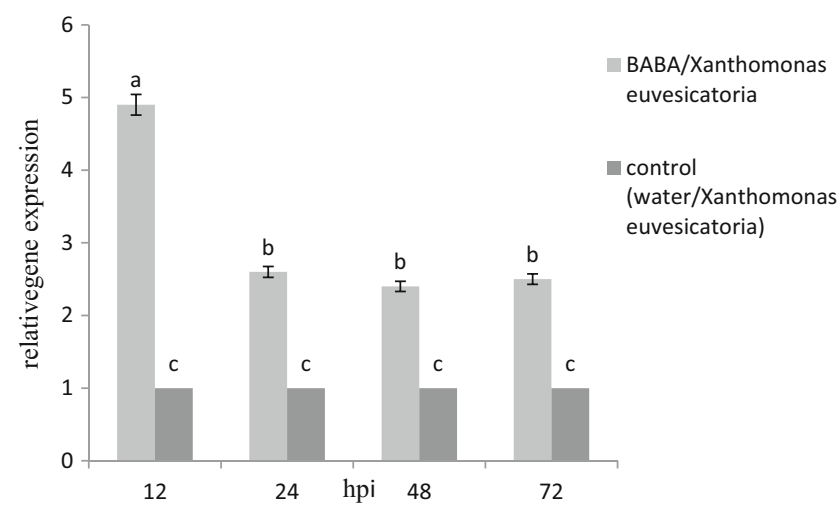

Fig. 3 Expression of $P R-1$ in pepper plants treated with BABA compared to the control. Significant difference was found in expression of PR-1 between BABA/Xanthomonas euvesicatoria and water/ Xanthomonas euvesicatoria at all time points. The maximum expression was observed at $12 \mathrm{hpi}$

Zimmerli et al. (2001) showed that BABA increases expression of $P R-1$ during induced resistance by BABA in Arabidopsis to Botrytis cinerea. In contrast, no accumulation of PR proteins was found in induced resistance by BABA in cauliflower, sunflower and lettuce against Peronospora parasitica, Puccinia helianthi and Bremia lactucae, respectively (Silue et al. 2002; Amzalek and Cohen 2007; Cohen et al. 2010). Hence, it seems that induction of $P R$ genes is not the only mechanism of resistance induced by BABA. Additionally, expression of defense genes during BABAinduced resistance might depend on plant species, pathogen and their interaction. It can be speculated that pre-treatment with BABA leads to an oxidative burst of ROS upon pathogen attack. This leads to increased amounts of CAT which balances ROS and acts as a signal for stimulation of other defense responses such as systemic acquired resistance (Alvarez et al. 1998), phytoalexin production (Daudi et al. 2012) and callose deposition (O'Brien et al. 2012). Increased antioxidant enzyme activity can occur in tomato during promoted resistance

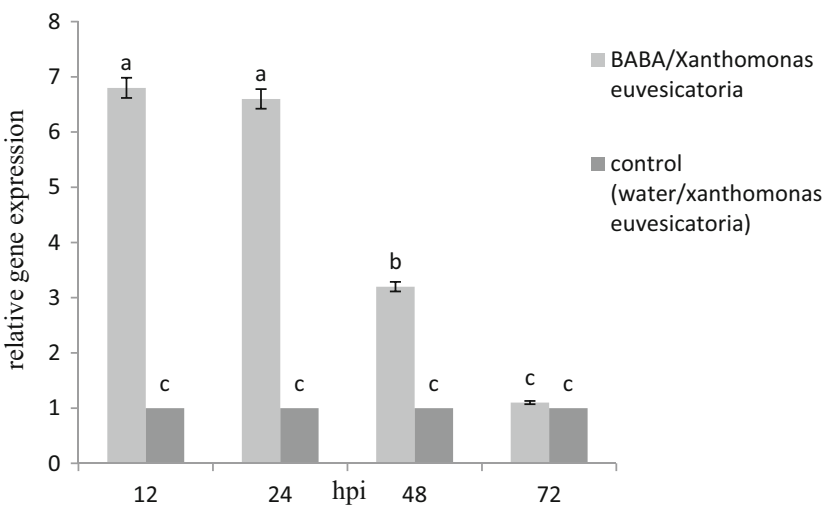

Fig. 4 Expression of $C A T$ in pepper plants treated with BABA compared to the control. Significant difference was found in expression of $C A T$ between BABA/Xanthomonas euvesicatoria and water/Xanthomonas euvesicatoria at 12, 24 and $48 \mathrm{hpi}$. The maximum expressions were found at 12 and $24 \mathrm{hpi}$ 
induced by BABA against Meloidogyne javanica (Sahebani and Hadavi 2009). CAT activity was increased in tomato by BABA following Pseudomonas syringae pv. tomato invasion (Baysal et al. 2007). In summary, the role of BABA for enhancing resistance of pepper against $X$. euvesicatoria was confirmed in this study. Our research has shown that the reduction in disease severity by BABA may be correlated with the activation of some defense genes such as $P R-1$ and $C A T$.

\section{References}

Alvarez ME, Pennell RI, Meijer PJ, Ishikawa A, Dixon RA, Lamb C (1998) Reactive oxygen intermediates mediate a systemic signal network in the establishment of plant immunity. Cell 92: 773-784

Amzalek E, Cohen Y (2007) Comparative efficacy of systemic acquired resistance-inducing compounds against rust infection in sunflower plants. Phytopathology 97:179-186

Baccelli I, Mauch-Mani B (2016) Beta-aminobutyric acid priming of plant defense: the role of ABA and other hormones. Plant Mol Biol 91:703-711

Baysal O, Gursoy YZ, Ornek H, Cetinel B, Da Silva JAT (2007) Enhanced systemic resistance to bacterial speck disease caused by Pseudomonas syringae pv. tomato by DL-b-aminobutyric acid under salt stress. Physiol Plant 129:493-506

Cohen Y (2002) $\beta$-aminobutyric acid-induced resistance against plant pathogens. Plant Dis 86:448-457

Cohen Y, Rubin AE, Kilfin G (2010) Mechanisms of induced resistance in lettuce against Bremia lactucae by DL-b-aminobutyric acid (BABA). Eur J Plant Pathol 126:553-573

Daudi A, Cheng Z, O'Brien JA, Mammarella N, Khan S, Ausubel FM, Bolwell GP (2012) The apoplastic oxidative burst peroxidase in Arabidopsis is a major component of pattern triggered immunity. Plant Cell 24:275-287

Ebrahim S, Usha K, Singh B (2011) Pathogenesis related (PR) proteins in plant defense mechanism. Sci against. Microb Pathog 2:1043-1054

Fischer MJC, Farine S, Chong J, Guerlain P, Bertsch C (2009) The direct toxicity of BABA against grapevine ecosystem organisms. Crop Prot 28:710-712

Hassan MAE, Buchenauer H (2007) Induction of resistance to fire blight in apple by acibenzolar-S-methyl and DL-3-aminobutyric acid. J Plant Dis Prot 114:151-158

Hossain Z, Makino T, Komatsu S (2012) Proteomic study of $\beta$ aminobutyric acid-mediated cadmium stress alleviation in soybean. J Proteome 75:4151-4164

Justyna PG, Ewa K (2013) Induction of resistance against pathogens by $\beta$-aminobutyric acid. Acta Physiol Plant 35:1735-1748
Kamble A, Bhargava S (2007) $\beta$-aminobutyric acid-induced resistance in Brassica juncea against the necrotrophic pathogen Alternaria brassicae. J Phytopathol 155:152-158

Kousik CS, Ritchie DF (1996a) Mixed genotypes combined with copper sprays to manage bacterial spot of bell peppers. Phytopathology 86: 502-508

Kousik CS, Ritchie DF (1996b) Disease potential of pepper bacterial spot pathogen races that overcome the $B s 2$ gene for resistance. Phytopathology 86:1336-1343

Livak KJ, Schmittgen TD (2001) Analysis of relative gene expression data using real-time quantitative PCR and the $2^{-\Delta \Delta C T}$ method. Methods 25:402-408

Marcucci E, Aleandri MP, Chilosi G, Magro P (2010) Induced resistance by b-aminobutyric acid in artichoke against white mould caused by Sclerotinia sclerotiorum. J Phytopathol 158:659-667

Mejía-Teniente L, Durán-Flores FDD, Chapa-Oliver AM, TorresPacheco I, Cruz-Hernández A, González-Chavira MM, OcampoVelázquez RV, Guevara-González RG (2013) Oxidative and molecular responses in Capsicum annuиm L. after hydrogen peroxide, salicylic acid and chitosan foliar applications. Int J Mol Sci 14: 10178-10196

Mittler R, Vanderauwera S, Gollery M, Van Breusegem F (2004) Reactive oxygen gene network of plants. Trends Plant Sci 9:490 498

O'Brien JA, Daudi A, Finch P, Butt VS, Whitelegge JP, Souda P, Ausubel FM, Bolwell GP (2012) A peroxidase-dependent apoplastic oxidative burst in cultured Arabidopsis cells functions in MAMP-elicited defense. Plant Physiol 158:2013-2027

Osdaghi E, Taghavi SM, Hamzehzarghani H, Lamichhane JR (2016) Occurrence and characterization of the bacterial spot pathogen Xanthomonas euvesicatoria on pepper in Iran. J Phytopathol 164: $722-734$

Safaie Farahani A, Taghavi SM, Afsharifar A, Niazi A (2016) Effect of $\beta$ aminobutyric acid on resistance of tomato against Pectobacterium carotovorum subsp. carotovorum. J Plant Dis Prot 123:155-161

Sahebani N, Hadavi N (2009) Induction of $\mathrm{H}_{2} \mathrm{O}_{2}$ and related enzymes in tomato roots infected with root knot nematode $(M$. javanica) by several chemical and microbial elicitors. Biocontrol Sci Tech 19: 301-313

Silue D, Pajot E, Cohen Y (2002) Induction of resistance to downy mildew (Peronospora parasitica) in cauliflower by DL-b-aminonbutanoic acid (BABA). Plant Pathol 51:97-102

Tavallali V, Karimi S, Mohammadi S, Hojati S (2008) Effects of beta aminobutyric acid on the induction of resistance to Penicillium italicum. World Appl Sci J 5:345-351

Zimmerli L, Jakab G, Metraux JP, Mauch-Mani B (2000) Potentiation of pathogen-specific defense mechanisms in Arabidopsis by betaaminobutyric acid. Proc Natl Acad Sci 97:12920-12925

Zimmerli L, Métraux JP, Mauch-Mani B (2001) $\beta$-aminobutyric acid induced protection of Arabidopsis against the necrotrophic fungus Botrytis cinerea. Plant Physiol 126:517-523 